\title{
EVALUASI TINGKAT KEBISINGAN DI BANDARA SULTAN SYARIF KASIM II PEKANBARU
}

\author{
Aryo Sasmita ${ }^{1)}$ dan David Andrio ${ }^{1)}$ \\ ${ }^{1)}$ Program Studi Teknik Lingkungan, Fakultas Teknik, Universitas Riau \\ email: aryosasmita@gmail.com
}

\begin{abstract}
Abstrak
Tingginya tingkat mobilisasi dan perkembangan Pekanbaru menuju kota metropolitan beberapa tahun belakangan berhubungan langsung dengan pertumbuhan aktivitas transportasi, termasuk tranportasi udara. Bandara Sultan Syarif Kasim II menjadi bandara internasional mengakibatkan aktivitas bandara yang semakin tinggi. Aktivitas bandara Sultan Syarif Kasim II Pekanbaru berpengaruh terhadap peningkatan kebisingan dikawasan Bandara, sehingga diperlukan penelitian tentang kebisingan akibat aktivitas pesawat terbang. Perhitungan tingkat kebisingan sesuai dengan Keputusan Menteri Lingkungan Hidup No. 48 tahun 1996 dan Keputusan Menteri Tenaga Kerja No. 51 tahun 1999. Perhitungan menunjukkan Tingkat kebisingan tertinggi di kawasan Bandara Internasional Sultan Syarif Kasim II berada di landasan pacu selatan yaitu 88,63 dBA, sedangkan tingkat kebisingan terendah berada pada titik apron timur yaitu 77,72 dBa. Hasil perhitungan diketahui bahwa lama bekerja paling singkat berada di landasan pacu selatan, maksimal bekerja yang diperbolehkan pada daerah tersebut hanya 3,46 jam. Maksimal bekerja terlama di apron timur selama 43,05 jam. Oleh karena itu pekerja disekitar daerah yang memiliki kebisingan yang tinggi harus menggunakan Alat pelindung diri untuk mengurangi dampak kebisingan yang dihasilkan dari aktivitas Bandara
\end{abstract}

Katakunci: tingkat kebisingan, aktifitas bandara, transportasi udara

\begin{abstract}
The high degree of mobilization and development of Pekanbaru city to become the metropolis in recent years are directly related to the growth of transport activity, including air transportation. Sultan Syarif Kasim II Airport into an international airport which resulted in airport activity are higher. Activities Sultan Syarif Kasim II Airport Pekanbaru affect the increased noise area of service, so it is necessary to do research on aircraft noise caused by the activity. The calculation of the noise level in accordance with the Decree of the Minister of Environment No. 48 of 1996 and Decree of the Minister of Manpower No. 51, 1999. Calculations show the highest noise level in the area of International Airport Sultan Syarif Kasim II is located in the southern runway is $88.63 \mathrm{dBA}$. While the lowest noise level is at its eastern apron is 77,72 dBA. From the results of calculations known that the shortest working hour is South runway, maximum allowable working in the region only 3.46 hours. The longest working hour allowed in the eastern apron for 43.05 hours. Therefore, workers in surrounding areas that have a high noise should use PPE to reduce the impact of noise generated from service activitie.
\end{abstract}

Keywords: The noise level, the activity of airports, air transport 


\section{PENDAHULUAN}

Menurut KepMenLH no 48 tahun 1996, Kebisingan adalah bunyi yang tidak diinginkan dari usaha atau kegiatan dalam tingkat dan waktu tertentu yang dapat menimbulkan gangguan kesehatan manusia dan kenyamanan lingkungan. Tingkat kebisingan adalah ukuran energi bunyi yang dinyatakan dalam satuan decible disingkat dB. Baku tingkat kebisingan adalah batas maksimal tingkat kebisingan yang diperbolehkan dibuang ke lingkungan dari usaha atau kegiatan sehingga tidak menimbulkan gangguan kesehatan manusia dan kenyamanan lingkungan. Kebisingan berasal dari kata bising yang artinya semua bunyi yang mengalihkan perhatian, mengganggu, atau berbahaya bagi kegiatan sehari-hari, bising umumnya didefinisikan sebagai bunyi yang tidak diinginkan dan juga dapat menyebabkan polusi lingkungan (Cornwell,1998).

Dampak kebisingan menurut Doelle (1993), tingkat kebisingan sebesar 65 dBA kontinyu akan berdampak penyakit jantung, kebisingan sebesar 70 dBA akan mengakibatkan kelelahan mental dan fisik, gangguan psikomatis, serta kebisingan sebesar 80 dBA akan mengakibatkan kerusakan dan penurunan daya pendengaran.

Tingginya mobilisasi dan pertumbuhan di Pekanbaru menuju kota metropolitan beberapa tahun belakangan ini berlangsung sangat cepat. Dinas Kependudukan dan Pencatatan Sipil (Disdukcapil) Pekanbaru mencatat perkembangan jumlah penduduk Pekanbaru sangat tinggi. Kota Pekanbaru merupakan kota besar dengan jumlah penduduk 1.011.467 jiwa pada tahun 2014, dengan pertumbuhan penduduk sebesar $1,24 \%$ / tahun. (BPS, 2015).

Bersamaan dengan meningkatnya pertumbuhan penduduk di Pekanbaru, berpengaruh pada kebutuhan transportasi, terutama transportasi udara. Peningkatan status Bandara Sultan Syarif Kasim II menjadi bandara internasional mengakibatkan aktivitas bandara yang semakin tinggi. Tercatat jumlah pesawat yang datang dan berangkat di Bandara Internasional Sultan Syarif Kasim II pada tahun 2014 sebanyak $24-25$ pesawat per harinya dengan jumlah penumpang rata-rata 3351 orang (Dirjen Perhubungan Udara, 2015).

Diketahui aktivitas Bandara Sultan Syarif Kasim II Pekanbaru berpengaruh terhadap peningkatan kebisingan, sehingga diperlukan penelitian lebih lanjut tentang kebisingan akibat aktivitas pesawat terbang. Penelitian ini dilakukan untuk mendapatkan nilai tingkat kebisingan dan membandingkannya dengan baku mutu lingkungan sesuai Keputusan Menteri Negara Lingkungan Hidup Nomor 48 Tahun 1996 tentang baku tingkat kebisingan.

\section{METODE Studi pendahuluan}

Tahapan studi pendahuluan ini bertujuan dalam penentuan waktu dan titik sampling. Penentuan hari ditetapkan berdasarkan jumlah penerbangan perhari. Jumlah penerbangan di Bandara Internasional Sultan Syarif Kasim II Pekanbaru setiap hari nya mencapai 78 jadwal penerbangan dan ditetapkan pada hari sabtu 10 September 2016 untuk melakukan pengukuran tingkat kebisingan. Penentuan titik sampling sebanyak 5 titik sampling di area Bandara Internasional Sultan Syarif Kasim II Pekanbaru

\section{Pengumpulan data}

1. Pengumpulan data sekunder

Setelah perumusan masalah dan latar belakang dilakukan pengumpulan data sekunder untuk mendapatkan gambaran kondisi eksisting Bandara Internasional Sultan Syarif Kasim II Pekanbaru dan pemukiman disekitarnya.

2. Pengumpulan data Primier

Pengukuran Tingkat Kebisingan

Pengukuran tingkat kebisingan di area bandara dilakukan selama jam operasional bandara yaitu dari pukul 06.00 WIB - 24.00 WIB, Pengumpulan data

Tahap pengumpulan data ini mencakup :

a. Tingkat tekanan suara (Lp)

b. Data meteorologi yang meliputi kecepatan angin dan arahnya, suhu, dan kelembaban udara.

\section{Pengolahan dan analisi data}

1. Pengolahan dan perhitungan data 
Langkah pengolahan dan perhitungan data adalah Perhitungan tingkat kebisingan sesuai dengan Keputusan Menteri Lingkungan Hidup No. 48 tahun 1996 yang dikeluarkan pada tanggal 25 november 1996 berisi tentang metode pengukuran, perhitungan, dan evaluasi tingkat kebisingan lingkungan.

2. Analisis data dan pembahasan Evaluasi kebisingan

Dari hasil pengolahan data dapat ditarik kesimpulan mengenai kondisi kebisingan di Bandara Internasional Sultan Syarif Kasim II Pekanbaru dan pemukiman sekitarnya. Tingkat kebisingan yang dievaluasi berdasarkan pada :

a. Keputusan Menteri Lingkungan Hidup No. 48 tahun 1996 yang dikeluarkan pada tanggal 25 november 1996 berisi tentang metode pengukuran, perhitungan, dan evaluasi tingkat kebisingan lingkungan.

b. Keputusan Menteri Tenaga Kerja No. 51 tahun 1999 tentang nilai ambang batas faktor fisika ditempat kerja lampiran II nilai ambang batas kebisingan.

\section{Lokasi Penelitian}

Pada setiap titik lokasi, pengukuran kebisingan dilakukan dengan menggunakan alat Sound Level Meter (SLM). Untuk dapat membandingkan tingkat kebisingan pada empat lokasi tersebut maka pengukuran harus dilakukan dengan jarak dan ketinggian yang sama. Ukuran ketinggian ditetapkan masing-masing $\pm 1,5$ meter. Sumber bising utama adalah suara pesawat yang akan take off, landing dan aktivitas yang sedang berlangsung.

Titik pengukuran kebisingan di kawasan Bandara Internasional Sultan Syarif Kasim II Pekanbaru terbagi menjadi 5 titik. Titik pengukuran kebisingan selengkapnya dapat dilihat pada Tabel 1 dibawah ini.

Tabel 1. Lokasi Titik Pengukuran Kebisingan

\begin{tabular}{cll}
\hline No. & $\begin{array}{c}\text { Titik Pengukuran } \\
\text { Kebisingan }\end{array}$ & \multicolumn{1}{c}{ Keterangan } \\
\hline 1 & Landasan Pacu Utara & 20 meter dari landasan pacu pesawat terbang \\
2 & Landasan Pacu Selatan & 20 meter dari landasan pacu pesawat terbang \\
3 & Apron Timur & Area apron bandara, 250 m dari landasan pacu pesawat terbang \\
4 & Apron Selatan & Area apron bandara, 250 m dari landasan pacu pesawat terbang \\
5 & Area Parkir & Area parkir kendaran bermotor, 500 m dari landasan pacu \\
& & pesawat terbang \\
\hline
\end{tabular}

\section{Alat Penelitian}

Adapun peralatan yang digunakan dalam pengumpulan data adalah sebagai berikut :

1. Penelitian ini menggunakan Sound Level Meter (SLM)untuk mengukur tingkat kebisingan. SLM yang digunakan pada penelitian ini juga dapat digunakan untuk mengetahui data meteorologi seperti kecepatan angin, suhu, dan kelembaban udara.

2. Stopwatch yang digunakan untuk menghitung waktu pengukuran tingkat tekanan suara.

3. Alat tulis dan form survey untuk mencatat data sampling.

4. Perangkat komputer untuk mengolah data dan pemetaan kebisingan

\section{HASIL DAN PEMBAHASAN \\ Pengukuran Tingkat Kebisingan}

Pengukuran tingkat tekanan suara dilakukan pada hari sabtu, yaitu pada tanggal 10 September 2016 yang dilakukan di kawasan bandara Sultan Syarif Kasim II yang tersebar di 5 titik pengukuran. Pengambilan data dilakukan pada kondisi dan cuaca normal sehingga tidak mempengaruhi tingkat kebisingan yang sebenarnya.

Kondisi meteorologi merupakan faktor pendukung yang meliputi temperatur, kelembapan, arah dan kecepatan angin. Untuk lebih jelasnya, nilai kondisi meteorologi terukur dapat dilihat pada Tabel 2. 
Tabel 2. Nilai Kondisi Meteorologi Terukur

\begin{tabular}{cc}
\hline \multicolumn{2}{c}{ Kondisi Meteorologi } \\
\hline Temperatur $\left({ }^{0} \mathrm{C}\right)$ & $25,1-38,1$ \\
Kelembaban $(\%)$ & $48,7-89,6$ \\
Kecepatan angin $(\mathrm{m} / \mathrm{s})$ & $0,0-2,6$ \\
Arah angin dominan & Tenggara \\
\hline
\end{tabular}

Data tingkat tekanan suara $\left(\mathrm{L}_{\mathrm{P}}\right)$ diukur setiap 5 detik selama 10 menit pada rentang waktu yang telah ditentukan sehingga data yang dihasilkan untuk satu titik pengukuran adalah 120 data. Dari hasil pengukuran diketahui tingkat tekanan suara di kawasan bandara berada pada rentang
33,9 - 114,2 awaktu. Nilai Leq yang diperoleh pada waktu pengukuran di kawasan Bandara adalah $(65,29$ - 96,61) dBA. Rekapitulasi hasil Perhitungan nilai $\mathrm{L}_{\mathrm{eq}}$, pada masing-masing waktu pengukuran dapat dilihat pada Tabel 3 dibawah ini.

Tabel 3. Rekapitulasi Tingkat Kebisingan di Area Bandara

\begin{tabular}{cccccc}
\hline \multirow{2}{*}{ Titik Pengukuran } & \multicolumn{5}{c}{ Perhitungan Leq(dBA) } \\
\cline { 2 - 6 } & Leq 1 & Leq 2 & Leq 3 & Leq 4 & Leq 5 \\
\hline Landasan Pacu Utara & 81,79 & 80,24 & 79,17 & 89,00 & 69,59 \\
Landasan Pacu Selatan & 92,12 & 86,86 & 92,46 & 75,08 & 77,54 \\
Apron Timur & 78,32 & 77,30 & 79,77 & 75,48 & 73,14 \\
Apron Selatan & 76,00 & 77,47 & 94,66 & 72,55 & 72,18 \\
Area Parkir Kendaraan & 90,93 & 96,61 & 66,01 & 81,86 & 65,29 \\
\hline
\end{tabular}

Dari $\mathrm{L}_{\mathrm{eq}}$ nilai dilakukan pengolahan data untuk mendapatkan nilai $\mathrm{L}_{\mathrm{S}}, \mathrm{L}_{\mathrm{M}}$, dan $\mathrm{L}_{S M}$. Rekapitulasi hasil perhitungan nilai $\mathrm{L}_{S}$,
$\mathrm{L}_{\mathrm{M}}$, dan $\mathrm{L}_{\mathrm{SM}}$ pada masing-masing waktu pengukuran dapat dilihat pada Tabel 4 dibawah ini

Tabel 4. Rekapitulasi Nilai $\mathrm{L}_{S,} \mathrm{~L}_{\mathrm{M}}, \mathrm{L}_{S M}$

\begin{tabular}{cccc}
\hline Titik Pengukuran & $\mathbf{L}_{\mathbf{S}}(\mathbf{d B A})$ & $\mathbf{L}_{\mathbf{M}}(\mathbf{d B A})$ & $\mathbf{L}_{\mathbf{S M}}(\mathbf{d B A})$ \\
\hline Landasan Pacu Utara & 85,12 & 69,59 & 84,66 \\
Landasan Pacu Selatan & 89,02 & 77,54 & 88,63 \\
Apron Timur & 77,66 & 73,14 & 77,72 \\
Apron Selatan & 87,63 & 72,18 & 87,17 \\
Area Parkir Kendaraan & 92,33 & 65,29 & 91,82 \\
\hline
\end{tabular}

Dari Tabel 4 di tingkat kebisingan tertinggi di kawasan Bandara Internasional Sultan Syarif Kasim II berada di landasan pacu selatan yaitu 88,63 dBA. Sedangkan tingkat kebisingan terendah berada pada titik apron timur yaitu 77,72 dBA. NIOSH (1998) dan Departemen Tenaga kerja RI menetapkan $85 \mathrm{dBA}$ sebagai nilai ambang batas maksimum yang diperbolehkan selama 8 jam bekerja. Jika dibandingkan tingkat kebisingan Lsm dengan nilai ambang batas, sehingga titik pengukuran landasan pacu utara dan apron timur yang masih berada dibawah nilai ambang batas yang diperbolehkan.

\section{Evaluasi Tingkat Kebisingan}

Untuk kawasan bandara mengacu pada Keputusan Menteri Tenaga Kerja No. KEP-51/MEN/1999 tentang nilai ambang batas kebisingan ditempat kerja, maksimal tingkat kebisingan yang diperbolehkan adalah 85 dBA selama 8 jam sehari.

Berikut hasil perhitungan lama paparan kebisingan yang diperbolehkan selama 8 jam perharinya. 
Tabel 5. Durasi Paparan Kebisingan yang Diperbolehkan

\begin{tabular}{ccc}
\hline Titik Pengukuran & Kebisingan Rata-rata (dBA) & T (Jam) \\
\hline Landasan Pacu Utara & 84,66 & 8,65 \\
Landasan Pacu Selatan & 88,63 & 3,46 \\
Apron Timur & 77,72 & 43,05 \\
Apron Selatan & 87,17 & 4,81 \\
\hline
\end{tabular}

Contoh perhitungan durasi paparan kebisingan yang diperbolehkan di area landasan pacu utara,

$$
\begin{gathered}
\mathrm{I}=\frac{480}{2^{(\mathrm{L}-\mathrm{CL}) \mathrm{ER}}} \\
\mathrm{I}^{\prime}=\frac{480}{2^{(84,66-85) / 3}} \\
\mathrm{I}=519,80 \text { Menil }, \mathrm{I}=8,65 \mathrm{Jam}
\end{gathered}
$$

Dari Tabel 5 diatas diketahui bahwa lama bekerja paling sebentar untuk landasan pacu pelatan, maksimal bekerja yang diperbolehkan pada daerah tersebut hanya 3,46 jam., dan terlama di apron timur 43,05 jam. Oleh karena itu pekerja yang berada ditempat tersebut harus menggunakan Alat Pelindung Diri (APD) untuk mengurangi dampak kebisingan yang dihasilkan dari aktivitas Bandara.

Dengan jam kerja rata-rata 8 jam sehari, Menurut NIOSH (1998), ambang batas maksimum untuk waktu yang diperkenankan untuk bekerja sebesar 8 jam adalah sebesar $85 \mathrm{dBA}$. Berdasarkan tabel 5, diketahui pada apron timur yang memiliki tingkat kebisingan rata-rata paling rendah, pekerja dapat bekerja lebih lama dari pada 3 titik pengukuran lain. Kebisingan di tempat kerja merupakan masalah utama dalam kesehatan kerja di berbagai negara. Hasil penelitan ini sejalan dengan hasil penelitian Tana (2002), yang mneyatkan Dengan terpapar kebisingan > 85 dBA secara terus-menerus dapat meningkatkan resiko noise induced hearing loss. Kurang pendengaran akibat bising terjadi secara perlahan, dalam waktu hitungan bulan sampai tahun. Hal ini sering tidak disadari oleh penderitanya, sehingga pada saat penderita mulai mengeluh kurang pendengaran, biasanya sudah dalam stadium yang tidak dapat disembuhkan (Sukar, 2003).
Pembatasan jam bekerja pada lokasi yang memiliki tingkat kebisingan yang tinggi sangat diperlukan. nilai bising yang bersifat menetap lebih merusak dibandingkan bising terus menerus. Akibat dari intensitas, sifat bising, waktu kerja, melebihi batas yang diperbolehkan, maka bising dapat menimbulkan gangguan pendengaran bagi tenaga kerja dan masyarakat sekitar Bandara, penelitian Hartono (2006) menyebutkan Kebisingan dari aktivitas pesawat udara dengan Taraf Intensitas 92,29 dB, dengan lama paparan lebih dari 1 tahun dapat menyebabkan kondisi stress Alarm stage pada masyarakat di sekitar Bandara Adi Sumarmo Boyolali.

\section{KESIMPULAN}

1. Tingkat kebisingan tertinggi di kawasan Bandara Internasional Sultan Syarif Kasim II berada di landasan pacu selatan yaitu 88,63 dBA. Sedangkan tingkat kebisingan terendah berada pada titik apron timur yaitu 77,72 dBA

2. Dari hasil perhitungan diketahui bahwa lama bekerja paling sebentar untuk landasan pacu pelatan, maksimal bekerja yang diperbolehkan pada daerah tersebut hanya 3, 46 jam., dan terlama di apron timur 43,05 jam sehingga pekerja harus menggunakan APD untuk mengurangi dampak kebisingan yang dihasilkan dari kegiatan Bandara.

\section{Ucapan Terima Kasih}

Penulis mengucapkan terimakasih kepada semua pihak yang telah berkontribusi dalam penyelesaian tulisan ini, antara lain keluarga penulis, manajemen dan pegawai Bandara Internasional Sultan Syarif Kasim II Pekanbaru, serta civitas akademika Prodi Teknik Lingkungan FTUR. 


\section{DAFTAR PUSTAKA}

Badan Pusat Statistik (BPS) Kota Pekanbaru. 2015. Pekanbaru dalam angka 2015.

Cornwell, Davis. 1998. Introduction to Environmental Engineering. McGraw-Hill, Int.

Direktorat Jendral Perhubungan Udara. 2015. Data Keberangkatan Pesawat. Kementerian Perhubungan Republik Indonesia.

Doelle, L Leslie. 1993. Akustik Lingkungan. Erlangga Press. Surabaya.

Hartono. 2006. Pengaruh Perbedaan Intensitas Kebising-An Terhadap Jumlah Limfosit Pada Masyarakat di Sekitar Bandara Adi Sumarmo Boyolali. Enviro. Vol 7, No.2. 20-24.

Keputusan Menteri Lingkungan Hidup No. 48 tahun 1996 tentang Metode Pengukuran, Perhitungan, dan Evaluasi Tingkat Kebisingan Lingkungan.

Keputusan Menteri Tenaga Kerja No. KEP-51/MEN/1999 tentang Nilai Ambang Batas Kebisingan Ditempat Kerja

National Institute for Occupational Safety and Health (NIOSH). 1998. Occupational Noise. Exposure revised criteria 1998. Cincinnati, Ohio;

Sukar, dkk. 2003. Jurnal Ekologi Kesehalan Vol2 No I. April 2003: 185 - 191

Tana, Lusianawaty., dkk. 2002. Gangguan Pendengaran Akibat Bising Pada Pekerja Perusahaan Baja Di Pulau Jawa. Jurnal Kedokteran Trisakti. Edisi SeptemberDesember 2002, Vol.21 No.3. 